\title{
Quality control of airborne geophysical data from the EU Mining Sector Support Programme, Ghana
}

\author{
Thorkild M. Rasmussen, Leif Thorning, Arne V. Olesen and Frands Schjøth
}

On 2 December 2002, EU Commissioner Poul Nielson on behalf of the European Development Fund signed a $€ 40$ million grant to the Ghana Government. The purpose of this grant was to finance a Mining Sector Support Programme (MSSP) that covered a broad spectrum of geoscientific projects and other projects aimed at an overall strengthening and modernisation of Ghana's mining sector. One of the major components was collection and interpretation of airborne geophysical data contracted to the two commercial geophysical companies Fugro Airborne Surveys and Geotech Airborne Ltd. The Geological Survey of Denmark and Greenland (GEUS) was contracted to perform the quality control (QC) of the airborne geophysical data collection and processing in a separate MSSP project (No 8 ACP GH 027/37). The initial Provision of quality-control services to the Airborne Geophysical Survey required GEUS to be on site in Ghana for 22 man-months; an expansion of the programme and various circumstances (see below) resulted in a total of 37.25 man-months before the project was completed in January 2010. The Danish National Space Center was subcontracted by GEUS to perform part of the QC of gravity data acquisition and processing. The $\mathrm{QC}$ project was reported by Thorning et al. (2010).

Results from some of the geoscientific projects of the MSSP were presented at a workshop in 2008 and a series of small articles from the presentations were published (Kalsbeek 2008).

\section{Organisational setup for the airborne geophysics projects within the MSSP}

Interactions between GEUS and several organisations were required in order to carry out the project. The Geological Survey Department (GSD) within the Ministry of Lands and National Resources of Ghana was the main beneficiary institution of the airborne geophysical surveying. A GSD employee acted as supervisor of the projects to collect airborne geophysical data as well as of the QC project. In reality three persons were appointed during the four-year course of the project. Other organisations involved were the MSSP Programme Management Unit established under a separate contract and supervised by the Minerals Commission. This is the main promotional and regulatory body for the minerals sector in Ghana, which acted as executing organisation for the MSSP. In addition, the European Delegation in Ghana and the National Authorising Officer of the Ministry of Finance of Ghana took part in the administration.

Contributions to the projects came from several of the two geophysical companies' offices; Fugro's offices in Accra, Johannesburg, Ottawa, Perth and London and Geotech's offices in Accra, Toronto and Johannesburg were involved.

The EU delegation and the National Authorising Officer undertook the contracting for the various MSSP projects. GEUS did not have formal obligations with respect to the technical specifications in the contract with Fugro Airborne Surveys, but a considerable amount of assistance from GEUS was required in order to clarify various technical issues. The contract with Fugro was signed before GEUS was awarded the QC project. GEUS assisted in setting up the tender documents for the airborne data collection project that was later awarded to Geotech Airborne Ltd. in 2008.

One of the lessons learned with respect to organising airborne geophysical survey projects similar to those performed in Ghana is that the QC team selected for the external quality control should be involved at an early stage and should be consulted concerning the setup of the tender specifications used for the contract with the geophysical consultant performing the measurements.

\section{The geophysical survey data}

The surveys performed by Fugro involved the following: (1) Remote sensing interpretation (in co-operation with British Geological Survey (BGS)), (2) acquisition and interpretation of airborne magnetic data, (3) acquisition and interpretation of airborne gamma-spectrometric data, (4) acquisition and interpretation of airborne gravity data and (5) acquisition and interpretation of airborne time-domain electromagnetic (GEOTEM) data. The surveys performed by Geotech Airborne Ltd. involved (1) Acquisition and interpretation of airborne magnetic data and (2) acquisition and interpretation of airborne time-domain electromagnetic (VTEM) data.

During all flights the surveys employed two methods simultaneously, of which magnetic data acquisition was one. 


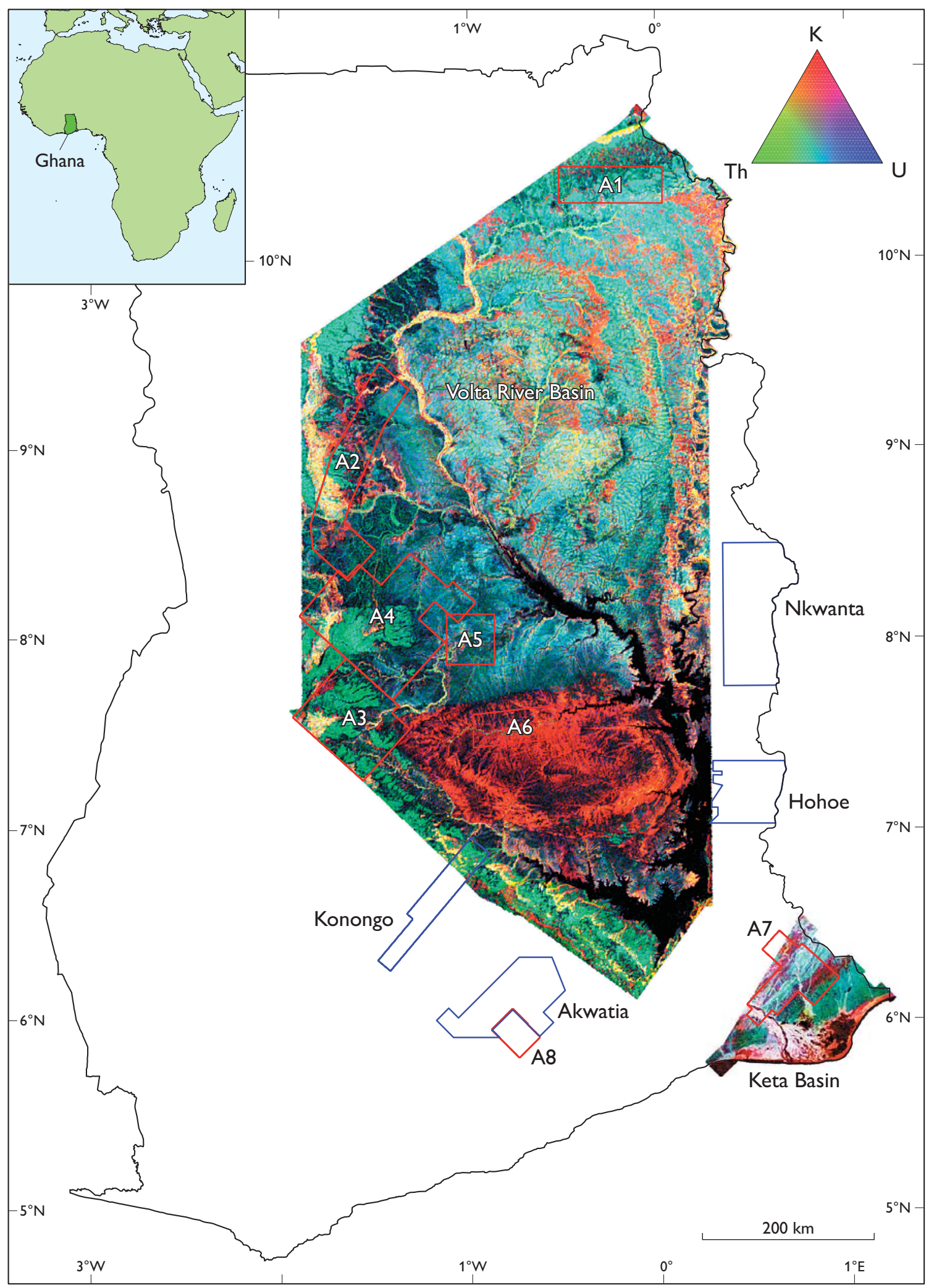

Fig. 1. Map of Ghana with ternary U-Th-K images of the gamma-ray spectrometry data from the Volta River and Keta basin surveys. Polygons show survey block boundaries for eight areas covered by detailed GEOTEM surveys (red colour) and for four areas covered by VTEM surveys (blue colour). 
The combined gamma-spectrometry and magnetic survey by Fugro included measurements of the horizontal gradient of the magnetic total field in addition to the magnetic total field recordings. The inclusion of the horizontal gradient data improved the lateral resolution in the description of the magnetic field anomalies. The surveys performed by Fugro used different fixed-wing aircraft as survey platforms, whereas a helicopter was used for the surveys performed by Geotech.

Figure 1 outlines the areas that were covered by the airborne surveys. The Volta River and Keta basins were surveyed by Fugro. These areas had not previously been covered by detailed airborne geophysical surveys, whereas most of the surrounding 'basement' had been covered before. With the completion of the two new surveys the entire onshore area of Ghana is now covered by high-resolution magnetic and gamma-spectrometry data. This puts Ghana in a leading po- sition with respect to providing modern airborne geophysical data to the mining industry. The Volta River and Keta basins gamma-spectrometric and magnetic surveys were flown with a $500 \mathrm{~m}$ line separation and a survey altitude of $120 \mathrm{~m}$. Gravity data were also obtained for the two basin areas, using a mean survey altitude of $860 \mathrm{~m}$ above ground and a flight line separation of $5000 \mathrm{~m}$.

Reconnaissance GEOTEM data were collected over the entire Volta River and Keta basins using $20 \mathrm{~km}$ flight-line separation. Later, the areas numbered A1-A8 in Fig. 1 were flown with the GEOTEM system using a flight-line separation of $200 \mathrm{~m}$ and $400 \mathrm{~m}$. The survey blocks referred to as Nkwanta, Hohoe, Akwatia and Konongo were subsequently flown with the VTEM system using $400 \mathrm{~m}$ line separation.

Initially, the surveys planned were mainly directed towards obtaining an understanding of the geology of the two basin areas and only included those performed by Fugro.

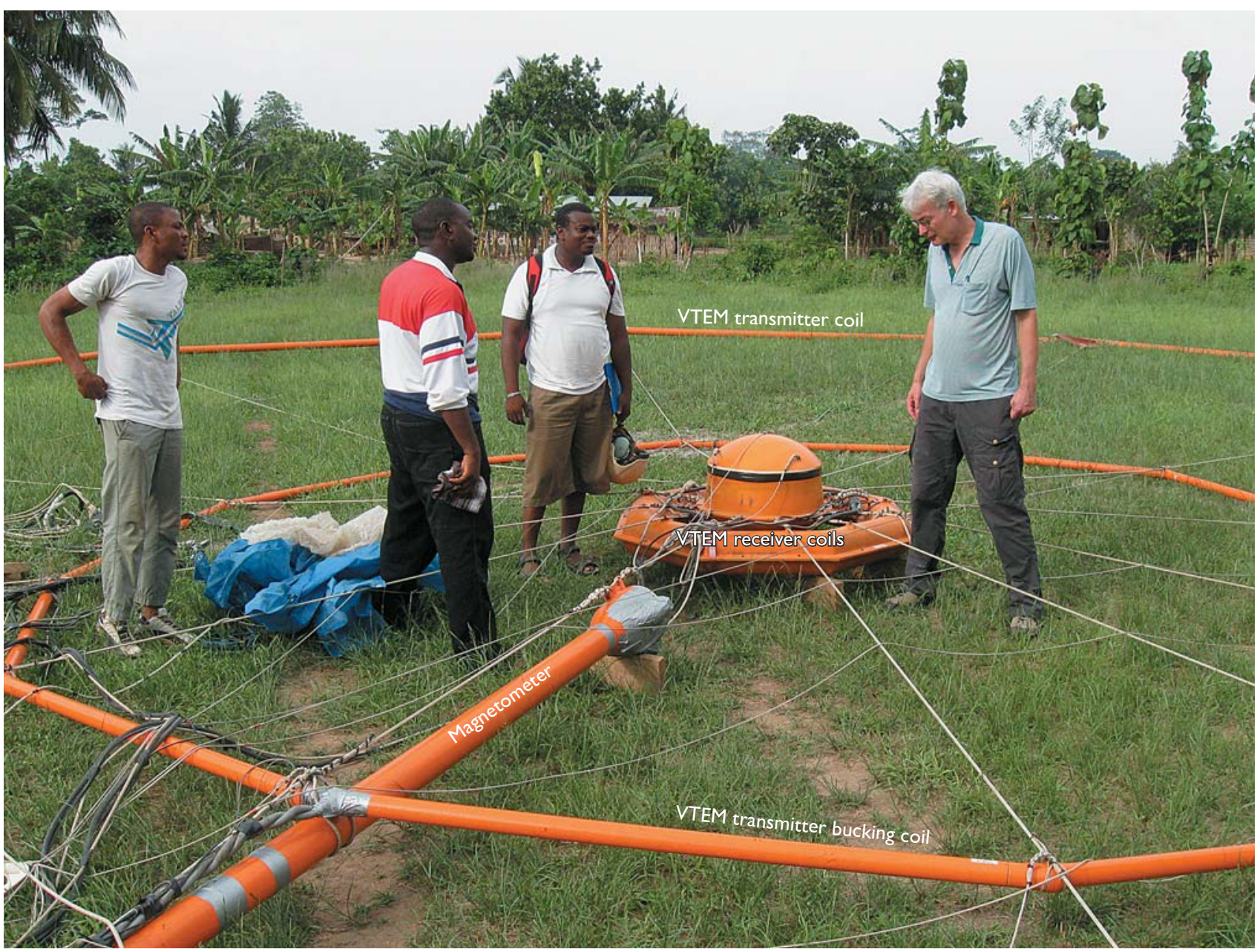

Fig. 2. The first author (right) discusses the methods of the VTEM system during a break in the surveying of the Akwatia block with the Geotech operators. The outer transmitter coil has a diameter of c. $26 \mathrm{~m}$ and carries a current of $c .200$ A before turn-off of the transient signal. 
The VTEM survey performed by Geotech was added to the MSSP at a late stage and focused on areas outside the basins. Fugro, BGS and Geotech performed geological field work as part of a follow-up of the airborne surveying. Other MSSP geoscientific projects had activities in the areas covered by the geophysical surveys, but the timing of the projects did not allow full integration of data from the various projects. The QC was expanded to include storing of the geophysical data on a server on the Geological Survey Department's computer system (Schjøth et al. 2010).

The quality control process carried out by GEUS was complex and sometimes very difficult, but mostly performed on good terms with the geophysical contractors. The quality of the final data now available in Ghana for the mining sector and the scientific community was often significantly improved by the process.

\section{QC and training of Geological Survey Department personnel}

The quality control performed by GEUS may be viewed as a data assessment independent of the geophysical contractors' own data quality control. Although independent, the quality control by the QC team builds on a high degree of interaction with the geophysical contractors (Fig. 2). Even though the QC team, the client and the geophysical contractors basically have the same goal of obtaining high-quality data, different views and interests may often exist in terms of defining a proper balance between data quality and project delays.

Analyses of data with respect to quality from a technical point of view are clearly a major concern of the QC team. Some of these analyses follow fairly standardised methodologies and checking procedures, whereas others require an in-depth understanding of data acquisition and processing techniques. In some cases, the acquired field data may be in accordance with the specifications and pass the first routine check, but subsequent application of more advanced checking procedures after the contractor's processing of the data may reveal problems that were not initially identified.

An important part of the obligations by GEUS was the inclusion of a training component involving two GSD employees and the production of a QC manual (Rasmussen et al. 2010) including examples of data issues dealt with during the project. The airborne geophysical contractors also trained GSD personnel. The contracts with GEUS and the two geophysical contractors were very ambitious with respect to involvement of GSD personnel in the projects. Significant knowledge transfer and interaction related to QC took place throughout the entire project period, through regular courses and especially intensive hands-on training provided by GEUS as part of the actual work with QC.

\section{Conclusions}

For obvious reasons the authors are somewhat subjective in assessing the impact of the work performed. Nevertheless, we conclude that the GEUS contribution did have significant influence on the quality of the data released from the project - a conclusion that is supported by statements of GSD personnel, the geophysical contractors and an independent evaluation committee. Furthermore, during the course of the project, a constructive working relationship between GSD and GEUS personnel was established that would be beneficial to both parties in future cooperation.

\section{References}

Kalsbeek, F. (ed.) 2008: The Voltaian Basin, Ghana. Workshop and excursion, March 10-17, 2008, 136 pp. Copenhagen: Geological Survey of Denmark and Greenland. http://www.geus.dk/program-areas/common/voltaian_workshop_report.pdf.

Rasmussen, T.M., Thorning, L. \& Olesen, A.V. 2010: Quality control manual for airborne geophysics. The European Development Fund. Project no. 8 ACP GH 027/37. Mining Sector Support Programme. Geophysical investigation. Danmarks og Grønlands Geologiske Undersøgelse Rapport 2010/42, 207 pp.

Schjøth, F., Rasmussen, T.M. \& Thorning. L., 2010: Guide to the GSD DAP-server depository for airborne geophysical data. Danmarks og Grønlands Geologiske Undersøgelse Rapport 2010/43, 69 pp.

Thorning, L., Rasmussen, T.M. \& Schjøth, F. 2010: Final report. Provision of quality control services to the airborne geophysical survey. The European Development Fund. Project no. 8 ACP GH 027/37. Mining Sector Support Programme. Danmarks og Grønlands Geologiske Undersøgelse Rapport 2010/44, 35 pp.

\footnotetext{
Authors' addresses

T.M.R., L.T.H. \& F.S.C., Geological Survey of Denmark and Greenland, Øster Voldgade 10,DK-1350 Copenhagen K, Denmark. E-mail: tmr@geus.dk. A.V.O., DTU Space, National Space Institute, Technical University of Denmark, Juliane Maries Vej 30, DK-2100 Copenhagen $\emptyset$, Denmark.
} 